\title{
IMAGENS DE LÍNGUA NO DISCURSO DO PROFESSOR: AS LÍNGUAS BANTU PREJUDICAM A APRENDIZAGEM DO PORTUGUÊS?'
}

Sheila Perina de Souza²

Resumo: Este artigo insere-se na discussão sobre o ensino e aprendizagem das línguas bantu e da língua portuguesa. Com a independência em 1975, Moçambique tornou o português língua oficial para o ensino. Em 2003, com o Plano Curricular do Ensino Básico, o país incluiu as línguas bantu no ensino básico pela primeira vez. Apesar dessa política linguística, Ngunga e Bavo (2011) constataram que, em 2007, ainda havia escolas que proibiam o uso das línguas bantu. Diante desse cenário que demonstra certa hostilidade histórica ao uso das línguas bantu, questionamos aos professores em formação universitária se o ensino das línguas bantu prejudicaria a língua portuguesa. Tivemos como objetivo analisar as imagens de língua presente no discurso desses professores. Teoricamente nos inspiramos nas formações imaginárias de Pêcheux (1993). Observamos que nos discursos proferidos pelos professores ainda há imagens de línguas que podem ser associadas a formações discursivas coloniais. Esses discursos carregam a imagem de que pode haver prejuízo no ensino das línguas bantu caso ele não esteja atrelado à aprendizagem do português. Ao mesmo tempo constatamos a circulação de discursos que se contrapõem a imagem de que as línguas bantu prejudicariam o ensino da língua portuguesa. Tais discursos consideram que o ensino das línguas bantu podem atuar como: a) suporte para a aprendizagem do português. b) meio para a resolução dos problemas escolares; c) meio de valorização cultural. No discurso dos professores, também observamos a imagem de língua que coloca as línguas bantu em paridade com as línguas europeias.

Palavras-chave: línguas bantu; imagens de língua; discurso dos professores

\section{Introdução}

Moçambique é um país multilíngue e multicultural, o português é a língua oficial desde a independência em 1975, mesmo convivendo com dezenas de línguas locais, todas do grupo bantu. Vinte dessas línguas são oficialmente denominadas línguas nacionais, são elas: o cicopi, o cinyanja, o cinyungwe, cisenga, cisena,

\footnotetext{
${ }^{1}$ Este texto é fruto da dissertação de mestrado "Imagens de língua: Um estudo educacional a respeito das línguas bantu na escola moçambicana" apresentada na Faculdade de Educação da Universidade de São Paulo, no ano 2020.

${ }^{2}$ Doutoranda em Educação pela Faculdade de Educação da USP, Mestra em Educação e graduada em pedagogia pela mesma instituição.E-mail: sheilaperina@hotmail.com
} 
cinyanja, cishona, ciyao, echuwabo, ekoti, elonwe, gitonga, cimaconde, kimwani, emakhuwa, memane, cisuaíli, suazi, xichangana, xironga, e xitswa e zulu. Elas também são frequentemente chamadas de línguas moçambicanas ou línguas bantu. De acordo com o Relatório do III Seminário Padronização da Ortografia de Línguas Moçambicanas, 17 dessas línguas já têm a sua escrita padronizada. (NGUNGA \& FAQUIR, 2012).

Apesar da língua portuguesa ser a única língua oficial, circulando em Maputo verificamos que as línguas bantu estão presentes nos chapas, nos mercados, feiras e principalmente no ambiente familiar. Nas escolas o ensino é feito na maior parte das instituições em língua portuguesa. Nos últimos anos, após um longo período de proibição do uso dessas línguas na escola (desde a colonização), o Plano Curricular do Ensino Básico (2003) inseriu essas línguas no ensino por meio do ensino bilingue e também através do uso das línguas bantu como auxiliares no ensino feito em português.

Mesmo após as línguas bantu terem sido incorporadas no sistema de ensino moçambicano, constatou-se uma certa hostilidade relativa ao seu uso em 2007, no dossiê Práticas linguísticas em Moçambique: Avaliação da vitalidade linguística em seis distritos de Ngunga e Bavo (2011). Os autores apresentaram os resultados da pesquisa sobre a vitalidade linguística em Moçambique com base em uma investigação realizada em seis distritos de três províncias. Nesse estudo, os pesquisadores avaliaram os esforços desenvolvidos por Moçambique, desde a independência, para o resgate das línguas moçambicanas.

Essa pesquisa constatou que, em 2007, ainda havia escolas que proibiam o uso das línguas bantu e castigavam os alunos severamente pelo uso. Os pesquisadores constataram que, devido à postura punitiva da escola, quando questionados sobre o que pensavam das línguas bantu, os estudantes, com medo das represálias, "preferiram dizer que não gostavam das línguas moçambicanas, e até não gostavam de quem falasse tais línguas e que nunca teriam amigos falantes destas línguas.” (NGUNGA \&BAVO, 2011, p. 65)

Diante desse cenário, que demonstra uma certa hostilidade histórica ao uso das línguas bantu na escola, desde o período colonial, decidimos questionar os professores se eles acreditavam na afirmação de que o ensino da língua bantu prejudicaria a aprendizagem da língua portuguesa, visto que eles foram escolarizados, em sua maioria, entre o início da década de 90 e os anos 2000, e viveram experiências de marginalização linguística durante o ensino básico.

No momento da investigação os professores colaboradores desta pesquisa cursavam a licenciatura em ensino básico, um curso que forma professores para lecionar nas séries iniciais, em uma universidade pública de Moçambique. Questionário aplicado questionavam os professores a respeito de diversos aspectos no uso da língua. Para este artigo escolhemos a questão "Há pessoas que afirmam que o ensino das línguas bantu prejudicaria a aprendizagem da língua portuguesa. O que pensas disso?” 
Por meio da análise das respostas investigamos as diferentes imagens de língua que circulam no discurso do professor sobre os prejuízos e benefícios das línguas bantu na escola.

\section{Imagens de língua no discurso do professor}

A noção de imagem usada por nós está ancorada na Análise do Discurso de linha francesa, mais especificamente no conceito de formações imaginárias de Pêcheux (1993). Embasados pela explicação de Orlandi (2001), entendemos o discurso como o efeito de sentido que é construído a partir de um processo de interlocução. Para a pesquisadora citada, "[o] discurso não é fechado em si mesmo e nem é do domínio exclusivo do locutor: aquilo que se diz significa em relação ao que não se diz, ao lugar social do qual se diz, para quem se diz em relação a outros discursos". (ORLANDI, 2011, p.83)

A opção pela Análise do Discurso de linha francesa, para interpretar os dizeres presentes na escola acerca da língua do aluno, surge do interesse em estabelecer uma análise menos ingênua e mais politizada a respeito dos usos linguísticos, visto que essa área do conhecimento busca analisar os textos a partir do contexto, considerando os aspectos históricos e sociais dos sujeitos envolvidos na enunciação. As teorias advindas possibilitam uma análise mais fundamentada da relação entre a linguagem e a exterioridade. Seguimos Orlandi (2005) que considera que todo dizer é marcado pela ideologia que está presente nos discursos utilizados pelos sujeitos.

Batista (2011) em seu texto "Imagens do professor de língua portuguesa em concursos públicos da Grande São Paulo” inspirada em Pecheux (1993) considera que os discursos e as ideologias são resultados da posição social que os sujeitos ocupam, esse lugar na estrutura social é determinante tanto para a assimilação quanto para a disseminação dos discursos. Ao mesmo tempo que o discurso é uma mostra do lugar ocupado pelo sujeito, na enunciação esse sujeito pode se antecipar e se colocar no lugar do outro, na intenção de presumir o sentido que o discurso pode assumir para o outro.

Para Pêcheux $(1993,1998)$, todo processo discursivo presume a existência de formações imaginárias. Ou seja, todo processo discursivo supõe uma antecipação, um imaginário, uma representação acerca dos envolvidos nesse processo. $\mathrm{Na}$ produção do discurso, o teórico aponta a existência do lugar de A "destinador" e de B "destinatário", determinados na estrutura da formação social. O autor alerta que essa relação não se trata necessariamente de uma transmissão de informações entre A e B, mas sim de "efeitos de sentidos". A e B designam algo que difere da presença física, afinal são lugares representados nos processos discursivos, o que se efetiva nesse processo discursivo são antecipações. Isto é, as representações que A e B fazem de si mesmo e do outro. $O$ autor explica que no processo discursivo "é uma série de formações imaginárias que designam o lugar de A e B se atribuem cada um a si e ao outro, a imagem que eles fazem de seu 
próprio lugar e do lugar do outro.” (PÊCHEUX,1993, p. 82). Nesse jogo imaginário, além das formações imaginárias de $\mathrm{A}$ e $\mathrm{B}$, também são incluídas as imagens do objeto do discurso, as imagens desses três elementos são chamadas de jogo imaginário por Pêcheux (1993).

Neste trabalho buscamos olhar paras as imagens do objeto do discurso, neste caso a língua, e não para os interlocutores em seus lugares de A e B. Quando questionamos os professores a respeito dos possíveis prejuízos relativos ao ensino das línguas bantu na aprendizagem na língua portuguesa, buscamos analisar, nesse discurso as imagens das línguas bantu no discurso dos professores.

\section{Por que as línguas bantu prejudicam a aprendizagem da língua portuguesa?}

Ao questionarmos os professores moçambicanos a respeito da possibilidade de prejuízo causado pelas línguas bantu ao ensino de língua portuguesa tivemos por base em uma experiência vivida em Angola, em que constatamos certa hostilidade ao uso das línguas africanas na escola por parte da direção, fato que consideramos fruto de um passado colonial que proibia o uso dessas línguas na escola.

Em 2014, por meio de um intercâmbio financiado pela CAPES, estudamos um semestre na Universidade Lueji A’konde, na cidade do Dundo, na província da Lunda Norte em Angola. Na ocasião, também atuamos como professora de mais de 100 crianças que estavam na primeira classe do ensino primário em uma escola pública da região durante três meses. Durante este período as questões linguísticas relacionadas a educação tornaram-se alvo de nossos interesses na pesquisa.

Ao longo do processo, fui compreendo que havia uma falta de familiaridade com a língua portuguesa por parte de alguns de meus alunos que tinham, em sua maioria, a língua cokwe como língua materna. Embora a língua materna de meus alunos fosse o cokwe, toda escola era organizada em língua portuguesa, desde os diálogos em sala de aula aos materiais didáticos. A língua cokwe permanecia à margem do sistema de ensino.

$\mathrm{Na}$ escola, refletindo sobre esse contexto, em que eu nem sempre conseguia me comunicar de maneira eficiente com parte dos alunos, considerei que os outros professores falantes de cokwe usassem a língua materna dos alunos em sala de aula. Então, questionei a direção da escola sobre o uso da língua cokwe em sala de aula, foi afirmado que não era permitido o seu uso, pois a língua cokwe poderia prejudicar a aprendizagem da língua portuguesa. Todavia, também era comum ouvir professoras falando em cokwe nos corredores e na hora do intervalo.

A imersão neste contexto linguístico angolano, em que a língua cokwe, uma língua africana, ocupa um lugar marginal colaborou para o nosso interesse em compreender o o lugar das línguas africanas em Moçambique, um país que também vivenciou a colonização, visto que esses países vivenciaram um histórico de opressão linguística parecido. 
Nos países que foram colônias de Portugal, observamos uma histórico de proibição das línguas africanas. Destacamos o Decreto Português 77, de 9 de dezembro de 1921, que proibia o uso das línguas africanas nas escolas. Atualmente, pode-se observar marcas dessa legislação nas escolas desses países em que a língua portuguesa ocupa lugar central enquanto as línguas africanas ocupam um lugar a margem.

Ao analisarmos esse histórico de imposição da língua portuguesa, associada à inibição do uso das línguas africanas em Angola, sob o argumento de que elas poderiam prejudicar o ensino, aventamos a possibilidade de que esses discursos poderiam também estar em voga na sociedade moçambicana atualmente, assim como verificamos em Angola. Consideramos que analisar a presença de discursos como esse contribui para compreensão dos limites das políticas linguísticas oficiais que tem pautado a inclusão das línguas bantu no ensino moçambicano

Assim questionamos os professores em formação, que em grande parte já atuavam no sistema de ensino básico.

Questão:

Há pessoas que afirmam que o ensino das línguas bantu prejudicaria a aprendizagem da língua portuguesa. O que pensas disso?

A pergunta foi respondida por 38 professores em formação no ano de 2016. Esses professores faziam o curso de licenciatura em ensino básico, haviam cursado um semestre de uma disciplina que discute aspectos da didática em línguas bantu. $\mathrm{Na}$ análise, observamos a formação de três grupos de respostas.

- No grupo 1, estão as respostas que considera que as línguas bantu prejudicam;

- No grupo 2, estão as respostas que relativizam os prejuízos que as línguas bantu podem causar na aprendizagem do português;

- No Grupo 3, estão as respostas que considera que discordam plenamente sobre a possibilidade das línguas bantu prejudicarem o ensino.

- Primeiramente, observemos as respostas do grupo 1 e $2^{3}$.

$\overline{{ }^{3} \text { Optamos por manter a grafia original das respostas. }}$ 


\section{0 ensino das línguas bantu prejudica a aprendizagem da língua portuguesa}

Abaixo estão as tabelas que contém as repostas dos três grupos, o número a direito refere-se a número do questionário. Primeiramente observemos a tabela 1 , que tem as respostas do grupo 1 e 2 . Nesta tabela estão os professores que consideram que o uso das línguas bantu poderiam trazer prejuízo ou condicionam este prejuízo a outros fatores.

Tabela 1: Respostas dos professores que consideram que o ensino prejudica ou condicionam este prejuízo a outro fator

\begin{tabular}{|r|l|}
\hline \multicolumn{2}{|c|}{ Grupo 1 - Prejudicam } \\
\hline $\mathbf{2 5}$ & $\begin{array}{l}\text { Prejudicar, no sentido ensino, sim, porque retarda o hábito da criança desenvolver a } \\
\text { capacidade do vocabulário próprio, sem auxílio da língua local. }\end{array}$ \\
\hline $\mathbf{2}$ & $\begin{array}{l}\text { Gão prejudica, porque a criança só aprende com a língua materna nos primeiros } \\
\text { ciclos quando vai do } 2^{\circ} \text { ciclo já se introduz a língua portuguesa }\end{array}$ \\
\hline $\mathbf{4}$ & $\begin{array}{l}\text { Para isso eu acho que não é verdade isto porque os alunos não aprendem só a língua } \\
\text { bantu eles ainda aprendem a língua portuguesa neste caso a língua bantu só auxilia } \\
\text { para melhor entender as matérias. }\end{array}$ \\
\hline $\mathbf{9}$ & $\begin{array}{l}\text { O ensino bilíngue quando ensinado ou implementado em zonas cuja língua portu- } \\
\text { guesa é vista como língua estrangeira, de modo algum prejudica a aprendizagem da } \\
\text { LP. Pois as línguas bantu são mesmo um meio de auxiliar para o ensino da L.P. }\end{array}$ \\
\hline $\mathbf{1 0}$ & $\begin{array}{l}\text { Prejudicaria sim, se olharmos para vertente em que os professores só ensinam em } \\
\text { línguas bantu não fazendo a lição com o português. }\end{array}$ \\
\hline $\mathbf{2 8}$ & $\begin{array}{l}\text { Acho que não prejudica, desde o momento que a língua portuguesa esteja enquadra- } \\
\text { da no ensino como disciplina e não como meio de ensino para facilitar a compreen- } \\
\text { são nas classes iniciais. }\end{array}$ \\
\hline $\mathbf{3 7}$ & $\begin{array}{l}\text { Não, penso que essas pessoas não estão erradas, o ensino de línguas bantu não pre- } \\
\text { judicaria o ensino pois teria a língua portuguesa como auxiliar }\end{array}$ \\
\hline
\end{tabular}

SOUZA, 2020

Entre os 38 professores que responderam ao questionário, apenas um professor defendeu que as línguas bantu poderiam causar prejuízo ao processo de ensino-aprendizagem. $O$ professor da resposta 25 acredita que o ensino de uma língua bantu retarda a aquisição do vocabulário em português. Outros professores indicaram a presença de prejuízo, mas ele foi o único professor que não condicionou sua resposta a outro fenômeno que poderia amenizar o prejuízo do uso língua materna, por exemplo.

No segundo grupo, estão os professores que condicionam o prejuízo causado pelo ensino das línguas bantu ao não uso da língua portuguesa. No discurso desses professores, observamos que a principal preocupação é com aprendizagem da 
língua portuguesa. Nesse grupo, notamos que a maioria dos professores não concorda com aqueles que afirmam que o ensino das línguas bantu prejudica o ensino da língua portuguesa, no entanto eles constroem um argumento condicionante.

Na resposta 2, o professor afirma que o ensino das línguas bantu não prejudica a aprendizagem da língua portuguesa e justifica dizendo que: “(...) a criança só aprende com a língua materna no primeiro ciclo quando vai do $2^{\circ}$ ciclo já se introduz a língua portuguesa”. Ao usar o advérbio “só”, ele reforça a ideia de condição. Ou seja, em sua visão, não haveria prejuízo, pois a língua bantu apenas seria ensinada por um curto período, somente no primeiro ciclo ou no segundo ciclo, depois a língua portuguesa estaria presente. A inserção da língua portuguesa no segundo ciclo garantiria que o ensino das línguas bantu não prejudicasse a aprendizagem da língua "principal". Observamos nesse discurso que a língua portuguesa tem sua imagem privilegiada quando comparada as línguas bantu.

O modelo bilíngue, adotado pelo governo para inserção das línguas bantu na escolarização, presente no Plano Curricular do Ensino Básico, é uma modalidade na qual as línguas bantu progressivamente perdem espaço no sistema de ensino para a língua portuguesa. Os alunos aprendem em uma língua bantu; e, depois o português é inserido como disciplina, até ele se tornar língua de ensino no $2^{\circ}$ ciclo. Tendo isso em vista, o professor parece ter pautado sua argumentação nesse modelo de ensino cuja finalidade é estabelecer o português como língua de ensino. A imagem de língua presente no discurso do professor na R.2, parece apresentar uma certa aproximação com as imagens de línguas disponibilizadas no Plano Curricular do Ensino Básico. Em ambos, as línguas bantu tem a imagem de língua transitória, que não permaneceria no ensino assim como o português.

Observemos a resposta 4 :"Para isso eu acho que não é verdade isto porque os alunos não aprendem só a língua bantu eles ainda aprendem a língua portuguesa neste caso a língua bantu só auxilia para melhor entender as matérias.” (grifos nossos). Nesse discurso, podemos ver a mesma lógica de argumentação sobre a defesa de que o ensino das línguas bantu não prejudica a aprendizagem da língua portuguesa, visto que os alunos não aprendem só a língua bantu, eles também aprendem o português. Ou seja, caso os alunos aprendessem "só" a língua bantu isso sim poderia ser prejudicial, mas como eles aprendem também a língua portuguesa o aprendizado como um todo não é prejudicado.

Observemos a resposta 37 "Não, penso que essas pessoas não estão erradas, $\underline{0}$ ensino de línguas bantu não prejudicaria o ensino pois teria a língua portuguesa como auxiliar". Nesta resposta observamos que o professor parece concordar com a afirmação de que ensino das línguas bantu prejudicaria a aprendizagem da língua portuguesa. Seguindo os outros colegas do grupo dois, o professor também condiciona sua resposta. Ele afirma que o ensino das línguas bantu não prejudicaria pois há a presenta da língua portuguesa como auxiliar.

Para o professor da resposta 10, a ausência da língua portuguesa no ensino das línguas bantu também poderia se configurar como prejuízo. O professor da 
resposta 10, argumenta que ocorre prejuízo sim, nos casos em que "os professores só ensinam em línguas bantu não fazendo a ligação com o português”. Nesse discurso, observamos que a experiência de aprendizagem de uma língua bantu é considerada um prejuízo caso não ocorra a ligação com o português.

Também no discurso da resposta 28 , o uso da língua portuguesa, no ensino das línguas bantu, ocupa lugar central para que não haja prejuízo. Na resposta 28 , o professor ressalta: "Acho que não prejudica, desde o momento que a língua portuguesa esteja enquadrada no ensino como disciplina e não como meio de ensino para facilitar a compreensão nas classes iniciais" (grifos nossos). Neste discurso o professor delimita um lugar para as línguas bantu, as classes iniciais. Em sua argumentação ele parece seguir modelo do ensino bilíngue presente no Plano Curricular do Ensino Básico, em que nos anos iniciais uma língua bantu é usada como língua de ensino ao mesmo tempo que a língua portuguesa está presente como disciplina.

O professor da resposta 9 diz "O ensino bilíngue quando ensinado ou implementado em zonas cuja língua portuguesa é vista como língua estrangeira, de modo algum prejudica a aprendizagem da LP. Pois as línguas bantu são mesmo um meio de auxiliar para o ensino da L.P”. Este professor também condiciona o prejuízo das línguas bantu para o ensino. No entanto, ele argumenta por outro viés: defende que se o ensino bilíngue for feito em localidades onde a língua portuguesa é vista como língua estrangeira, não haverá prejuízo ao ensino. Nas zonas rurais, o português é menos conhecido, logo, alguns linguistas consideram que nessas zonas o português é visto como uma língua estrangeira. Para o professor citado, então nessas zonas rurais, as línguas bantu não prejudicariam e tem uma função clara, meio de auxiliar o ensino da língua portuguesa. Esse discurso abre espaço para o argumento de defesa do ensino bilíngue somente nas zonas rurais. Tal discurso segue a mesma linha do Plano Curricular do Ensino Básico (2003) que prevê o ensino bilingue apenas para as rurais, consideradas linguisticamente homogêneas, nas zonas urbanas não há uma proposta de ensino bilingue. Ao que parece os discursos veiculados pelas políticas linguísticas oficiais, a partir de um lugar de poder, exercem influência no discurso dos professores.

No grupo dois, sobressai o argumento de que o ensino de línguas bantu não prejudicaria o ensino caso atuasse como auxiliar ou como disciplina, sempre em relação com a língua portugueses. Nos discursos dos professores desse grupo, parece não se vislumbrar um cenário em que o ensino das línguas bantu seja autônomo em relação à língua portuguesa. As línguas bantu parecem ter sua imagem veiculadas a uma suposta ameaça ao ensino do português.

Resgatando o Decreto Português 77, de 9 de dezembro de 1921, que proibia o uso das línguas africanas nas escolas, observamos no discurso dos professores um certo reflexo das prescrições deste Decreto. Percebemos como a formação discursiva colonial ainda circula nesses discursos que consideram que o ensino das línguas bantu por si só como um prejuízo, atribuindo a imagem de língua do ensino somente parta a língua portuguesa. Essa imagem de língua que considera um prejuízo o ensino das 
línguas bantu quando não atrelada a aprendizagem do português, pode restringir o uso dessas línguas em outras situações no ambiente escolar, dificultando a inclusão de politicas linguísticas que incorporem as línguas bantu no ensino.

\section{0 ensino das línguas bantu não prejudica a aprendizagem da língua portuguesa}

No grupo 3, estão os discursos dos professores que discordam da afirmação de que as línguas bantu podem prejudicar a aprendizagem da língua portuguesa. Esses professores se contrapõem às formações discursivas coloniais que inferiorizam as línguas africanas. Observamos nesses discursos um movimento de resistências as marcas coloniais presentes na escola moçambicana.

$\mathrm{Na}$ análise desses discursos observamos a formação de quatro categorias argumentativas na defesa do uso das línguas bantu. O primeiro grupo se utiliza de argumentos que convergem para uma imagem de que as línguas bantu podem ser suportes para a aprendizagem da língua portuguesa. O segundo grupo defende que as línguas bantu podem contribuir na resolução dos problemas escolares. $\mathrm{O}$ terceiro grupo defende que o uso das línguas bantu pode colaborar para valorização cultural. O quarto se contrapõe a ideia de que as línguas bantu poderiam prejudicar, eles constroem argumentos que colocam as línguas bantu no mesmo nível que as línguas europeias.

Tabela 2: Línguas que não prejudicam a aprendizagem do português - Grupo 3.

Grupo 3: Discordam

Línguas Bantu como suporte para a aprendizagem da Língua Portuguesa

1 como passaporte para ensino da língua portuguesa

Não prejudicaria uma vez que as línguas bantus favorecem a inclusão das crianças

14 nas escolas. As línguas bantus são meios de ensino, daí que funciona como auxiliar da língua portuguesa

33

Acho que não, porque existem crianças que entendem bem a sua língua local, e aprendendo através da sua língua fica fácil para entender já na língua portuguesa.

As línguas bantu não prejudicam a aprendizagem do Português pelo contrário auxi-

36 liam na compreensão do vocabulário em Português pois o aluno tem o vocabulário na língua só vai fazer a transferência para o Português

Acho que não porque há crianças que sabem contar usando sua língua ronga ou

6 changana mais não sabem identificar o um então nesse sentido facilita a transferência de aprendizagem 
Continuação da Tabela 2: Línguas que não prejudicam a aprendizagem do português - Grupo 3.

\section{Grupo 3: Discordam}

\section{Resolução dos problemas}

3

11

Não porque as línguas bantu veio para ajudar os alunos problemático ou com dificuldade na aprendizagem, para ajudar.

O ensino das línguas bantu não prejudicam a aprendizagem da língua portugue-

21 sa, reduz muitas reprovações, permite que o aluno tenha o domínio da sua própria língua.

É negativa essa apreciação, pois as línguas bantu aparecem com o propósito de resolver o grande problema do insucesso escolar

\section{Melhora a aprendizagem}

35 Não estou de acordo com essas pessoas pois a mesma facilita a compreensão do conhecimento, comunicação entre as pessoas pouco alfabetizadas.

27 Para mim não prejudica nada mas sim aumenta o nível de conhecimento na aprendizagem.

25 Considero a ideia muito (ilegível), pois a África bilíngue merece dar um salto importante na educação

Penso que não predicar a aprendizagem pelo contrário vai permitir que o aluno percebe os conteúdos tratados em língua portuguesa daí ela vai melhor assimilação.

Eu acho que essa ideia é negativa porque pensou-se em introduzir-se as línguas

23 bantu era para ajudar a melhorar o processo de ensino uma vez que cada criança tem a sua língua materna

34

Discordo plenamente com esse pensamento desses setores que defende isso, porque além não prejudicarem ajudam no processo de ensino de aprendizagem do aluno

38 Penso que não prejudica, mas sim ajuda na medida em que o aluno poderá se expressar colocando as suas dúvidas usando a língua que conhece

\section{Valorização cultural}

Pra (ilegível) contrário delas. Porque além de facilitar a aprendizagem da criança, também permite a valorização da sua língua como cultura, isto é, como direito.

24 A valorização de uma cultura tem a ver primeiro com a língua dessa cultura. Temos que valorizar a nossa língua, por usar o no ensino, na explicação dos conteúdos.

\section{Mesmo nível que as línguas europeias}

Do meu lado não vejo a possibilidade das línguas bantus prejudicarem a aprendiza- 
Continuação da Tabela 2: Línguas que não prejudicam a aprendizagem do português - Grupo 3.

\section{Grupo 3: Discordam}

\begin{tabular}{r|l}
\hline 12 & $\begin{array}{l}\text { Acho que a língua bantu não prejudica no ensino da língua portuguesa pois com o en- } \\
\text { sino da L.B. não significa que o aluno não deve aprender o português. Também poderia } \\
\text { perguntar se o ensino de inglês e francês prejudica? É mais uma língua para aprender. }\end{array}$ \\
\hline 17 & $\begin{array}{l}\text { O ensino de uma língua não pode prejudicar a aprendizagem de outra. Pessoas que } \\
\text { pensam que as línguas bantu prejudicam a aprendizagem do português tendem a } \\
\text { desvalorizar as línguas bantu. }\end{array}$ \\
\hline 19 & $\begin{array}{l}\text { Em nenhum momento uma língua prejudicaria o ensino de outra porque é possível } \\
\text { um indivíduo falar várias línguas. }\end{array}$ \\
\hline
\end{tabular}

\section{Língua Materna colabora}

\begin{tabular}{r|l}
\hline 8 & $\begin{array}{l}\text { Discordo plenamente, pois como já havia dito a criança aprende melhor com a lín- } \\
\text { gua na qual mais domina. }\end{array}$ \\
\hline 31 & $\begin{array}{l}\text { Não concordo com essas pessoas, uma vez que a criança aprende melhor na sua lín- } \\
\text { gua materna e que para Moçambique a maioria das crianças têm essas línguas como } \\
\text { L1 }\end{array}$ \\
\hline
\end{tabular}

\section{Outros argumentos}

22 Considero essa ideia errada.

SOUZA, 2020

\subsection{Imagens das línguas bantu - Suporte para a aprendizagem da Língua Portuguesa}

Os discursos presentes nesse grupo têm em comum a direção argumentativa: defende-se que a aprendizagem das línguas bantu não prejudicam o ensino da língua portuguesa, pois elas podem atuar como passaportes, como meios de ensino; ou, como auxiliares da língua portuguesa. Diferentemente dos colegas dos grupos 1 e 2, observamos nesses discursos o movimento em direção da incorporação das línguas bantu no cotidiano escola.

O professor da resposta 1 considera que as línguas bantu possibilitam o ensino do português, ele afirma: “(...) a línguas bantu no ensino permite às crianças como passaporte para ensino da língua portuguesa”. O uso do substantivo passaporte no sentido figurado parece indicar que o uso das línguas bantu na escola dá condições ou são um meio para a aprendizagem da língua portuguesa. Também para o docente da resposta 33, a aprendizagem das línguas bantu é considerada como um meio para a aprendizagem do português: “(...) aprendendo através da sua língua fica fácil para entender já na língua portuguesa”. Outro professor ressalta: "Acho que não porque há crianças que sabem contar usando sua língua: 
ronga ou changana mais não sabem identificar o um então nesse sentido facilita a transferência de aprendizagem (R.6). Também nesse discurso o não prejuízo da aprendizagem das línguas bantu está ancorado na possibilidade de elas atuarem a serviço da aprendizagem da língua portuguesa, facilitando a transferência. $\mathrm{O}$ uso de mais de uma língua na escola é visto como algo positivo.

$\mathrm{Na}$ mesma linha, que considera as línguas bantu como instrumento para o aprendizado, estão os discursos dos professores das respostas 14 e das respostas 36, o primeiro afirma: "As línguas bantus são meios de ensino, daí que funciona como auxiliar da língua portuguesa”. Outro professor, na resposta 36, argumenta que: "As línguas bantu não prejudicam a aprendizagem do Português pelo contrário auxiliam na compreensão do vocabulário em Português”. Notamos, então, que apesar dos professores considerarem positivo a inclusão das línguas bantu, o principal argumento é a possibilidade de auxiliar a língua portuguesa. As línguas bantu aparecem ocupando uma imagem de língua que deve assessorar o português.

Nos discursos analisados, o não prejuízo do ensino das línguas bantu está associado à defesa do uso dessas línguas como suporte para a aprendizagem do português - seja como meio de ensino, como auxiliares, passaportes ou como meio da transferência. A presença de um discurso que coloca as línguas bantu como suportes de aprendizagem do português pode ser observada no Plano Curricular do Ensino Básico (2003). O documento prevê a introdução das Línguas Moçambicanas no ensino em três modalidades, a segunda indica que as línguas bantu devem ser utilizadas como auxiliares. Observemos um trecho do item dois desse documento.

- Programa de ensino monolíngue em Português - L2 com recurso às Línguas Moçambicanas - L1.

Outra modalidade de utilização de línguas moçambicanas é como auxiliares do processo de ensino-aprendizagem no programa monolíngue Português (L2). Duas razões justificam esta modalidade:

- O próprio modelo de educação bilíngue adoptado prevê a utilização da L1 como auxiliar do processo de ensino aprendizagem principalmente a partir da 4a classe em que o meio de ensino principal é a língua portuguesa.

(...) Enquanto tal não é possível, deve-se encontrar uma estratégia em que se possa recorrer às línguas moçambicanas como auxiliares do processo de ensino aprendizagem, sobretudo nas zonas rurais onde a oferta linguística do Português é quase inexistente, como já referimos anteriormente. É assim, que se advoga o uso destas línguas como recurso, com metodologias apropriadas. (INDE/MINED, 2003, p.31- 32, grifos nossos).

Na ausência de possibilidade de se concretizar o ensino bilíngue, o Estado moçambicano avança propondo que as línguas bantu sejam usadas como auxiliares nas escolas monolíngues principalmente nas escolas das zonas rurais e, também, na educação bilíngue a partir da $4^{\mathrm{a}}$ classe, no meio em que se passa para a língua 
portuguesa. No momento que essa política linguística prevê um modelo de inserção das línguas bantu no ensino monolíngue, ela também disponibiliza uma imagem de língua, a das línguas bantu como auxiliares para o ensino de português. Os discursos dos professores que colocam a língua bantu no lugar de suporte ao ensino do português no grupo 2, e dos professores que consideram as línguas bantu como auxiliares no ensino, parecem ter sofrido influência do discurso vinculado por esse documento oficial.

\subsection{Imagens das línguas bantu - Línguas para a resolução do insucesso escolar}

No segundo grupo de professores, observamos a presença de um discurso que defende o uso das línguas bantu para o ensino, indicando que elas colaboram para a resolução das dificuldades e dos fracassos escolares.

O professor da resposta 3 afirma que: "as línguas bantu veio para ajudar os alunos problemático ou com dificuldade na aprendizagem”. Para esse docente, as línguas bantu são direcionadas àqueles alunos que têm dificuldade de aprendizagem. Desse modo, poderíamos inferir que os alunos que não apresentam dificuldades de aprendizagem não necessitam dessas línguas. No discurso resposta 11, as línguas bantu têm uma função clara na escola: "resolver o grande problema do insucesso escolar”. Parece que o ensino das línguas bantu seria somente para os alunos que possuem alguma defasagem no ensino, desafio no qual a língua se configura como um obstáculo.

Por outra vertente, o professor da resposta 21 enfatiza importância do domínio da língua materna para todos os alunos, ele afirma: "O ensino das línguas bantu não prejudicaria a aprendizagem da língua portuguesa, reduz muitas reprovações, permite que o aluno tenha o domínio da sua própria língua.” Também destacamos o argumento que dá relevância para o domínio da própria língua, visto que os argumentos que defendem o não prejuízo das línguas bantu não pautaram as contribuições intrínsecas à aprendizagem da língua, somente apresentaram justificativas pautadas em fatores externos à aprendizagem.

Em Moçambique, o uso das línguas bantu tem sido apontado como uma ferramenta para resolução das questões relacionadas ao insucesso escolar, esse discurso tem sido veiculado tanto pela Academia quanto pelo Estado.

\subsection{Valorização da cultura por meio do ensino da língua}

Neste item, estão os discursos dos professores defensores do ensino das línguas bantu e da sua contribuição para a valorização dessas línguas. Um dos docentes afirma: "[t]emos que valorizar a nossa língua, por usar no ensino, na explicação dos conteúdos.” (R24). Para esse professor, a valorização compreender usar tal língua no ensino e na explicação. Outro professor, (18), considera: "Porque além 
de facilitar a aprendizagem da criança, também permite a valorização da sua língua como cultura, isto é, como direito". Para tal professor, usar a língua na escola se configura como um direito cultural.

De modo geral, tem se popularizado o discurso de que é necessário valorizar as línguas minoritárias. Essa valorização tem sido veiculada, principalmente, pelos documentos oficiais, promotores de políticas linguísticas. A Constituição de Moçambique, por exemplo, propõe a valorização das línguas bantu, afirmando que “[o] Estado valoriza as línguas nacionais como património cultural e educacional e promove o seu desenvolvimento e utilização crescente como línguas veiculares da nossa identidade.” (MOÇAMBIQUE, 2004, p. 31).

Ainda que nos discursos dos professores apareça o argumento de valorização das línguas bantu, ao usarem o verbo valorizar, os docentes parecem transcender a ideia de valorização proposta pelo documento oficial. Essa extrapolação parece ocorrer porque os professores ampliam o conceito de valorizar, retirando-o da seara do ato de dar valor. No discurso da resposta 18 , o termo valorizar é usado para referir ao ensino das línguas bantu, e esse uso é visto como um direito cultural. O professor da resposta 24 também considera que valorizar é usar as línguas bantu no ensino e na explicação dos conteúdos. No discurso desses dois professores, valorizar ganha um novo significado, o termo assume o lugar da incorporação. Ou seja, deve-se incorporar as línguas bantu no ensino, assim como preconiza Barzotto (2004).

\subsection{Imagens das línguas bantu - Línguas Bantu em paridade com as línguas europeias}

O quarto grupo é composto pelos professores que argumentam que não haveria possibilidade do ensino das línguas bantu prejudicar o aprendizado de outras línguas. Por esse ponto de vista, as línguas bantu e as línguas europeias são colocadas no mesmo nível. Observemos os principais argumentos: "Do meu lado não vejo a possibilidade das línguas bantus prejudicarem a aprendizagem da língua portuguesa, pois se fosse o caso a língua inglesa prejudicaria também” (R.7). O professor da resposta 12 considera “[t]ambém poderia perguntar se o ensino de inglês e francês prejudica? É mais uma língua para aprender”. Outro professor defende que "[o] ensino de uma língua não pode prejudicar a aprendizagem de outra. Pessoas que pensam que as línguas bantu prejudicam a aprendizagem do português tendem a desvalorizar as línguas bantu"(R. 17). Por fim, o professor R.19 defende que "[e]m nenhum momento uma língua prejudicaria o ensino de outra porque é possível um indivíduo falar várias línguas”.

Os professores nos discursos presentes, R.7 e R.12, em suas argumentações invertem o questionamento, mostrando que se a aprendizagem de uma língua europeia não prejudica a aprendizagem de uma língua bantu, a proposição inversa também se confirma, logo o ensino das línguas bantu não prejudicaria a 
aprendizagem de uma língua europeia. Essa linha argumentativa defendida por esses professores contrapõe-se às formações discursivas coloniais que classificaram as línguas bantu a partir de um falso pressuposto de sua inferioridade. O professor da R.12 traz contribuições a partir de sua experiência e argumenta que a ideia de prejuízo é uma forma de desvalorização das línguas bantu. O professor, no discurso R.16, pontua que é possível um indivíduo falar várias línguas, tendo em vista que o domínio de várias línguas já é uma realidade para as pessoas africanas. Todavia, o sistema escolar tem negado o multilinguismo característico dessas populações.

De modo geral, a linha argumentativa apresentada por esse grupo marca um rompimento com as formações discursivas coloniais que hierarquiza as línguas, inferiorizando e marginalizando as línguas do continente africano. Ao se utilizarem de comparações entre as línguas bantu e as línguas europeias, os docentes entrevistados marcam a imagem de igualdade entre essas línguas e a ausência de prejuízo. $\mathrm{O}$ argumento construído demonstra que o ensino de nenhuma língua, seja europeia ou africana, não se configura um prejuízo para a aprendizagem de outras línguas.

\subsection{Imagens das línguas bantu - Aprende melhor nas línguas maternas}

O quinto grupo é composto pelo discurso por dois de professores que argumentaram que um estudante aprende melhor em sua língua materna. $O$ professor R.8 afirma que o aluno "aprende melhor com a língua na qual mais domina”. $\mathrm{O}$ outro professor afirma: "Não concordo com essas pessoas, uma vez que a criança aprende melhor na sua língua materna” (R.31).

Tal argumento de que as crianças aprendem melhor em sua língua materna tem sido amplamente defendido pela Universidade, pelo Governo e também pelas organizações internacionais. A Campanha Global pela Educação lançou uma campanha pela educação, intitulada "Ensino na língua materna: lições de política para a qualidade e inclusão" (2013). Nesse documento, é apresentado um conjunto de argumentos que busca demonstrar a importância da aprendizagem da língua materna nos primeiros anos de escolarização.

Quando a língua falada em casa e na escola é a mesma, verificou-se que há um nível mais alto de alfabetização. Um estudo realizado no Mali revelou que quando tinham cinco vezes menos probabilidades de repetir o ano e três vezes menos probabilidades de abandonar a escola. (Campanha Global pela Educação, 2013, p.04).

O Plano Curricular do Ensino Básico também considera que o "processo educacional, em qualquer sociedade, só terá sucesso se for conduzido através duma língua que o aprendente melhor conhece.” (INDE, 2003, p.33). Como observamos, o primeiro documento defende o uso das línguas maternas com base nas pesquisas científicas realizadas pelas Universidades; já o segundo documento não faz menção específica às contribuições da Universidade para tal afirmação. 
Ao que parece os professores defensores de que o ensino de línguas contribui para aprendizagem, mesmo respaldados pelos documentos oficiais e internacionais, também se apoiam nas próprias experiências em sala de aula.

\section{Considerações Finais}

Observamos que nos discursos proferidos pelos professores moçambicanos ainda há imagens de línguas que podem ser associadas a formações discursivas coloniais, que inferiorizam as línguas africanas e colocam-nas em disputa com a língua portuguesa. Esses discursos carregam a imagem de que pode haver prejuízo no ensino das línguas bantu caso ele não esteja atrelado aprendizagem do português. Consideramos que esse discurso pode atuar como um obstáculo pedagógico (BACHELARD, 1997) ao uso das línguas bantu ensino, pois poderá restringir o uso dessas línguas em outras situações no ambiente escolar em que não há uma ligação necessária entre essas línguas.

Ao mesmo tempo que observamos a circulação de discursos que se contrapõem a imagem de que as línguas bantu prejudicariam o ensino da língua portuguesa. Nesses discursos, as línguas bantu tem sua imagem atrelada a línguas que podem ser vistas como suportes para a aprendizagem da língua portuguesa. Também observamos discursos que aproximam as línguas bantu de línguas que podem contribuir na resolução dos problemas escolares. O terceiro grupo defende que as línguas bantu podem colaborar para valorização cultural. Por fim, no quarto grupo, vemos as línguas bantu tendo sua imagem aproximada das imagens construídas sobre as línguas europeias,

\section{LANGUAGE IMAGES IN THE TEACHER'S DISCOURSE: DO BANTU LANGUAGES HARM THE LEARNING OF PORTUGUESE?}

Abstract: This paper is part of the discussion on teaching and learning the Bantu and Portuguese languages. With independence, Mozambique made Portuguese the official language for teaching. In 2003, with the Basic Education Curriculum Plan, the country included Bantu languages for the first time. Despite this language policy, Ngunga and Bavo (2011) found that in 2007, there were still schools that prohibited the use of Bantu languages. In view of this scenario that demonstrates a certain historical hostility to the use of Bantu languages, we asked teachers in training if teaching Bantu languages would harm the Portuguese language. Our aim was to analyze the language images present in the speech of these teachers. Theoretically we are inspired by the imaginary formations of Pêcheux (1993). We observed that in the speeches given by the teachers there are still images of languages that can be associated with colonial discursive formations. These speeches carry the image that there may be a loss in the teaching of Bantu languages if it is not linked to learning Portuguese. At the same time, we noticed the circulation of speeches that oppose the image that the Bantu languages would harm the teaching of the Portuguese language. Such speeches consider that the teaching of Bantu languages can act as: a) support for learning Portuguese. b) means for solving school problems; c) cultural appreciation. In the teachers' discourse we also observe the 
language image that puts Bantu languages on par with European languages.

Keywords: Bantu languages; Tongue images; teachers' discourse

\section{Referências}

BACHELARD, Gaston. A Formação do espírito científico. Rio de Janeiro: Contraponto, 1997

BATISTA, Adriana Santos. Imagens do professor de língua portuguesa em concursos públicos da Grande São Paulo. Dissertação (Mestrado em Letras). Faculdade de Filosofia, Letras e Ciências Humanas, Universidade de São Paulo, São Paulo, 2011.

BARZOTTO. V. H. Nem respeitar, nem valorizar, nem adequar às variedades linguísticas. Ecos Revista, Cáceres, v. 2, p. 93-6. 2004.

INDE. Plano Curricular do Ensino Básico: objectivos, política, estrutura, plano de estudos e estratégias de implementação. Maputo, 2003.

MOÇAMBIQUE. Constituição. Constituição da República de Moçambique. Maputo, Assembleia da República. 2004.

NGUNGA, A.; BAVO, N. Práticas Linguísticas em Moçambique: Avaliação da Vitalidade Linguística em seis Distritos. Col. "As Nossas Línguas IV”.

CEA: Maputo, 2011.

Recebido em 23 de fevereiro de 2021

Aprovado em 10 de abril de 2021 